\title{
Empirical Analysis of Successful Factors of Financing in China's Crowdfunding Projects
}

\author{
Xiaohua Chen ${ }^{*}$ \\ *Corresponding Author \\ Xiaohua Chen \\ Article History \\ Received: 15.08 .2020 \\ Accepted: 22.08 .2020 \\ Published: 26.08 .2020
}

School of Insurance, Central University of Finance and Economics, Beijing, 100081, China

\begin{abstract}
Based on the quality signal and trust theory, this article constructs the crowdfunding financing process, summarizes and selects the important financing factors form the perspective of investors investment process, collects data from famous crowdfunding platforms in China, and empirically analyzes the factors influencing the successful financing of the crowdfunding projects. The empirical results show that the number of project pictures, the minimum amount of investment, the number of updates, the number of reviews, the number of backers and the backers of minimum amount of investment all positively and significantly affect the project's successful financing. This study is helpful to improve the successful financing rate of crowdfunding projects and promote the development of crowdfunding industry in China.
\end{abstract}

Keywords: Crowdfunding; quality signal; trust theory; financing factors.

\section{INTRODUCTION}

Crowdfunding is a new type of financing that allows small and medium-size enterprises, non-profit organizations or individuals to display project creative ideas to the public through the Internet, attracting public attention and obtaining funds to start projects, which can effectively solve the financial problems of the funds demand for their development and promote social entrepreneurial atmosphere and technological innovation [1]. The Thirteenth Five-Year Plan for China's National Economic and Social Development pointed out the need to comprehensively promote the development of crowdfunding, indicating that crowdfunding is formally included in the 13th Five-Year Plan of china. On the one hand, crowdfunding industry in china has developed rapidly in recent years, and has received more and more attention form the government; on the other hand, the actual completion rate of crowdfunding is still low, the financing efficiency is not high, and the successful financing rate needs to be improved. Thus, the in-depth exploration of the factors that affect the successful financing of crowdfunding projects will help increase the possibility of successful financing of projects and will be great significance in promoting the development of crowdfunding industry in China.

Regarding the research on the influencing factors of crowdfunding financing efficiency, most scholars used empirical research methods to collect representative crowdfunding platform data and used regression methods for analysis. The research found that the main factors affecting financing efficiency of crowdfunding project included: geographic location [2-4], amount of financing goal [5-7], number of support [5], project type [3,4], time of duration [4,6,7], amount of minimum investment [8], number of rewards [9,10], number of pictures [11], number of dynamic updates of project content [10,11], number of comments [12], video [12] and so on. Based on the existing literature, this article uses signal quality and trust theory to divide the project financing process into three specific processes, namely the process of attracting investors by quality signals in crowdfunding projects, fundraising process in which fundraisers and investors communicate with each other, and the process of the investor spending money to support project. Thus, the empirical model of influencing factors of successful financing in crowdfunding project is established to raise the financing efficiency of crowdfunding industry and promote the development of the industry.

Copyright @ 2020: This is an open-access article distributed under the terms of the Creative Commons Attribution license which permits unrestricted use, distribution, and reproduction in any medium for non commercial use (NonCommercial, or CC-BY-NC) provided the original author and source are credited. 


\section{THEORY AND RESEARCH MODEL}

This article divides the process of crowdfunded investors' funding support into three phases. First of all, the attraction process of quality signals of crowdfunding project to investors, which means that investors are attracted by quality, signals of the project during the warm-up period or the financing period when they browse the information. Second, the process of mutual communication and trust between the project sponsors and investors after investors having interested in the crowdfunding project, which means that the fund-raisers communicate with investors to reduce the information asymmetry of investors and increase their trust during the warm-up period or financing period of the project. Finally, when investors have an interest and trust in the project, it is very likely that they will enter into a funding-backed investment process. Only when the investor's total investment reaches or exceeds the amount of financing goal, the project is successfully financed; otherwise, the funds are returned to the investors. Figure-1 shows the three specific process of investor decision to support reward crowdfunding projects.

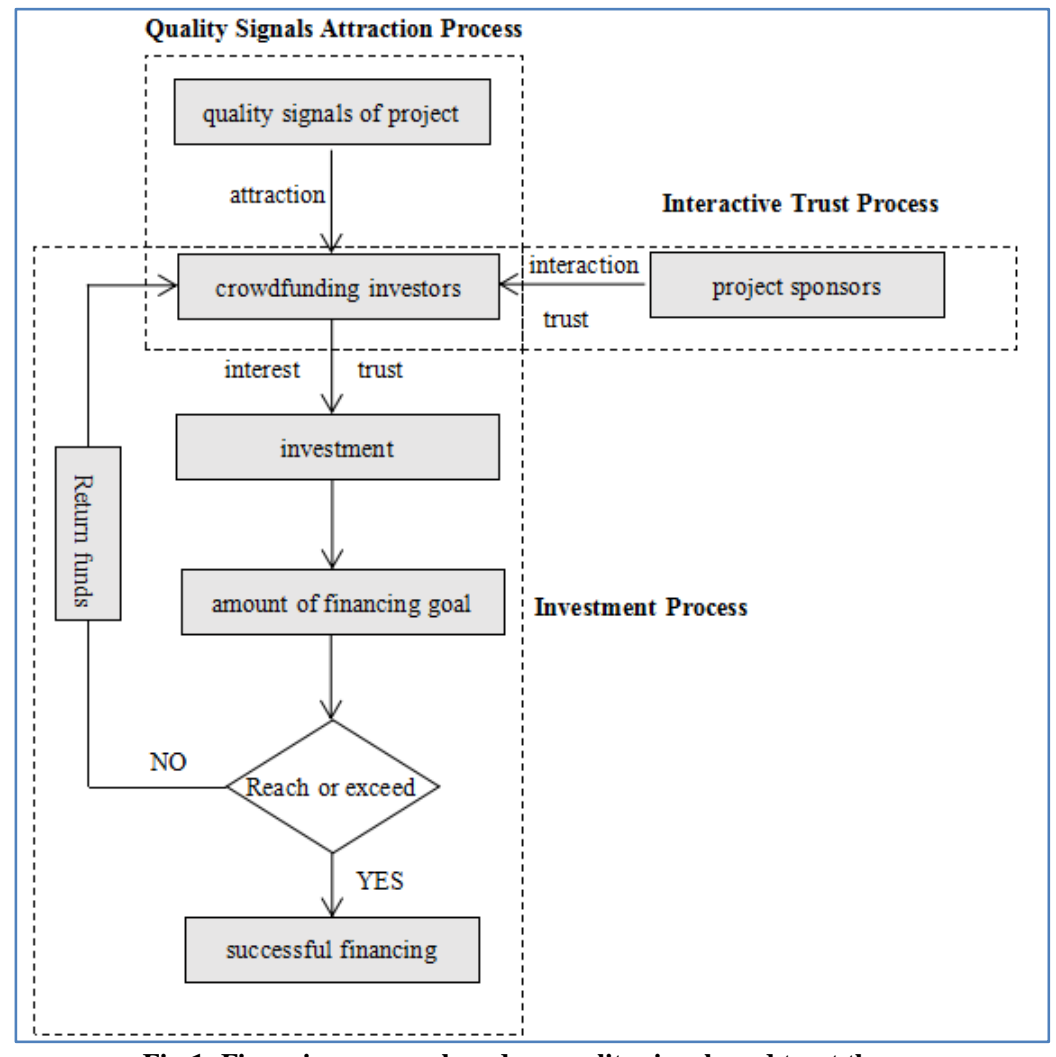

Fig-1: Financing process based on quality signals and trust theory

The quality signals are the basis of investors to judge crowdfunding product quality before making capital investment decisions, which are the signals that can reduce the perceived risk of their decision-making [12, 13], and the essence of the quality signals of the project is formed by signal transmission. In the attractive process of crowdfunding project to investors, the quality signals of project play an extremely important role. Yao et al., [12] based on the theory of quality signals, believed that the quality signals of the crowdfunding project contained entrepreneurial characteristics and project characteristics, and empirically analyzed the impact of various quality signals on successful financing and overfinancing of crowdfunding projects. Zheng et al., [14] based on the signal transmission theory, from the crowdfunding signals of human capital, uncertainty, and investment risk, empirically analyzed their impact on equity crowdfunding financing efficiency. Based on these studies, the quality signals of this paper refer to mainly crowdfunding characteristics, which are specifically reflected in the number of pictures, videos and return levels of the project, as well as the return corresponding to the minimum investment amount of the project.

Trust is the core element of online transactions in modern e-commerce. Many studies have shown that trust is an important factor affecting the process of users' online transactions [15]. Based on the theory of trust, Jiang [16] collected questionnaire data and constructed structural equations to empirically analyze the impact of trust on the willingness of users to pay for crowdfunding publishing projects. The study found that fundraisers' answers to investors' doubts and problems about the project can reduce investors' asymmetry in project information when fundraisers and investors communicate with each other, and can enhance investors' willingness to support crowdfunding projects through trust. Therefore, trust is an important factor in promoting investors' investment. Investors communicate with fundraisers in the commentary topic and project dynamic information section can generate trust about the crowdfunding project. 
In the process of investor's funds to support the project, under the "All or Nothing" crowdfunding financing rules, funds can only be obtained when the final fundraising amount reaches or exceeds the amount of financing goal; otherwise, it is necessary to return the raised funds to the investors. Therefore, the number of backers of the minimum return level, the total number of project backers, and the amount of financing goal are selected as the influencing factors in the investment process. In summary, the research model of this paper is shown in Figure-2.

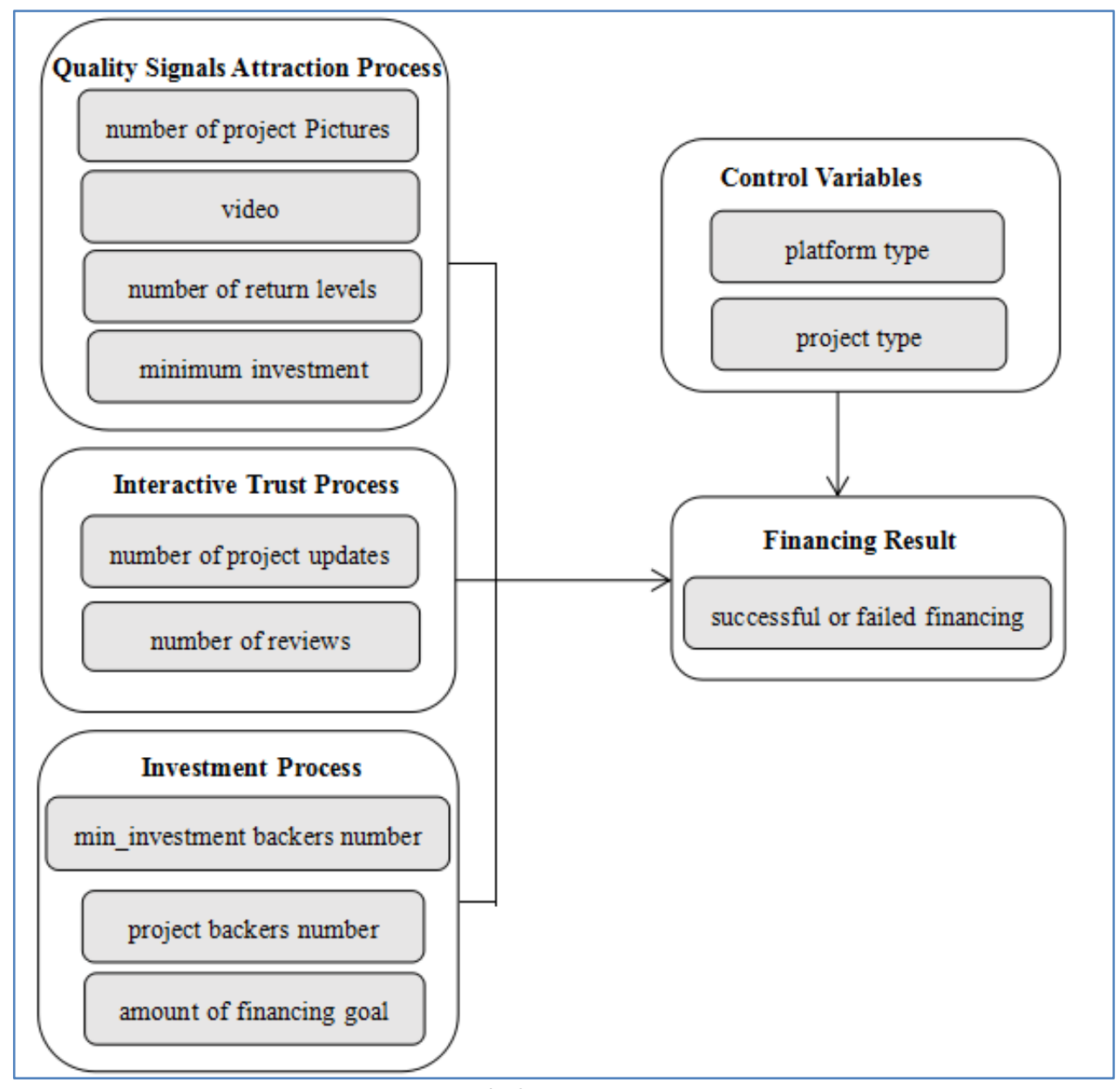

Fig-2: Research model

\section{EMPIRICAL ANALYSIS}

\section{Variables measurement}

We select the final financing result of the project as the explained variable. Successful financing is defined as " 1 " and financing failure is " 0 ". In addition, the process of decision-making investment of the investor to support crowdfunding project is divided into three stages: the investors attracted by the project quality signals, the investors generating trust from communicating with the fundraisers, and the investors finally supporting the project with funds. From these three stages of crowdfunding financing process, the important explanatory variables are selected respectively. The key explanatory variables selected for attractive process of the project quality signals are the number of project pictures, videos, the number of return levels, and amount of minimum investment. The key explanatory variables of the interactive trust process are number of project updates and number of comments. The key explanatory variables of the investor's investment process are the backer's number of minimum investment, project backer's number, and amount of financing goal. The specific meaning of explanatory variables is shown in Table-1. 
Table-1: Variable Description

\begin{tabular}{|c|c|c|c|}
\hline process & variable & logogram & variable description \\
\hline \multirow{4}{*}{$\begin{array}{l}\text { attractive process } \\
\text { of quality signals }\end{array}$} & $\begin{array}{l}\text { number of project } \\
\text { pictures }\end{array}$ & Images & $\begin{array}{l}\text { The number of pictures in the description of the } \\
\text { crowdfunding project. }\end{array}$ \\
\hline & video & Video & $\begin{array}{l}\text { If the description of the crowdfunding project } \\
\text { contains a video, it is defined as } 1 \text {, otherwise it is } 0 \text {. }\end{array}$ \\
\hline & number of return levels & Rewards & $\begin{array}{l}\text { The number of return levels set by fundraisers in } \\
\text { crowdfunding projects. }\end{array}$ \\
\hline & minimum investment & Min-inv & $\begin{array}{l}\text { The amount of minimum investment set by } \\
\text { fundraisers in crowdfunding projects. }\end{array}$ \\
\hline \multirow[t]{2}{*}{$\begin{array}{l}\text { interactive trust } \\
\text { process }\end{array}$} & $\begin{array}{l}\text { number of project } \\
\text { updates }\end{array}$ & Updates & $\begin{array}{l}\text { The number of times that fundraisers actively update } \\
\text { information of project progress. }\end{array}$ \\
\hline & number of reviews & Reviews & $\begin{array}{l}\text { The number of times that investors and fundraisers } \\
\text { discuss project topics. }\end{array}$ \\
\hline \multirow[t]{3}{*}{$\begin{array}{l}\text { investment } \\
\text { process }\end{array}$} & $\begin{array}{c}\text { min_investment backers } \\
\text { number }\end{array}$ & $\begin{array}{c}\text { Min- } \\
\text { inv_backers }\end{array}$ & $\begin{array}{l}\text { The number of investors supporting the minimum } \\
\text { investment. }\end{array}$ \\
\hline & project backers number & Backers & $\begin{array}{l}\text { The total number of investor backers from all return } \\
\text { levels. }\end{array}$ \\
\hline & $\begin{array}{l}\text { amount of financing } \\
\text { goal }\end{array}$ & Ln_goal & $\begin{array}{l}\text { The amount of financing goal set by fundraisers in } \\
\text { crowdfunding projects. }\end{array}$ \\
\hline
\end{tabular}

In addition, previous scholars believe that the type of crowdfunding project and the different platforms of crowdfunding projects will also affect the successful financing of the project. Therefore, we select crowdfunding project types and crowdfunding platforms as control variables.

\section{Data Collection}

Considering the scale, popularity, representativeness of crowdfunding platforms and whether historical financing failure data are retained or not, we choose to collect the data of four domestic well-known crowdfunding platforms in China, namely "Jingdong crowdfunding platform", "demohour platform", "dreamore platform", and "modian platform".

The "Jingdong crowdfunding platform" is a very popular in China and has a high reputation in reward crowdfunding industry. By July 2020, its successful financing amount has exceeded 7.266 billion RMB. Therefore, the samples of crowdfunding projects of Jingdong platform are well represented. We collected data of reward crowdfunding projects conducted by Jingdong platform from June to July of 2020, and removed samples of missing data and obtained 512 valid samples. The "demohour platform" was established as the first platform to introduce the crowdfunding model in China. It was once known as the "kickstarter" in China. We collected data as of July 2020 and compiled 864 valid sample data. The "Dreamore platform", founded in September 2011 and moved to mobile terminal in March 2015 to stop web services, has a large influence in the crowdfunding industry. We collected data from dreamore's webpage before moving to the mobile terminal, collected and compiled 928 valid sample data. The "Modian platform" is a crowdfunding platform focusing on cultural creativity and has a reputation in the field of cultural and creative industries. We collected data from its establishment date to July 2020 and compiled 513 valid sample data.

\section{DESCRIPTIVE STATISTICS}

Descriptive statistics on the collected crowdfunding project data, the results are shown in Table-2. There is a big gap between backer's number of minimum investment, project backers number, number of reviews, and number of project updates, which indicates that investors are very enthusiastic about participating in certain crowdfunding projects, but they are not enthusiastic about other projects. The gap of amount of the minimum investment among crowdfunding projects is also relatively large, which indicates that amount of the minimum investment for different types of crowdfunding projects varies greatly, and amount of the minimum investment for technological and designed projects is generally setting higher. 
Table-2: Crowdfunding Project Samples General Characteristics Descriptive Statistics

\begin{tabular}{|c|c|c|c|c|c|c|c|c|c|}
\hline & Images & Video & Rewards & Min-inv & Updates & Reviews & $\begin{array}{c}\text { Min- } \\
\text { inv_backers }\end{array}$ & Backers & Ln_goal \\
\hline mean & 10.86 & 0.41 & 6.04 & 101.99 & 18.54 & 26.64 & 48.62 & 143.56 & 9.08 \\
\hline minimum & 0 & 0 & 0 & 1 & 0 & 0 & 0 & 1 & 4.5 \\
\hline maximum & 69 & 1 & 51 & 9800 & 2917 & 2315 & 5000 & 7985 & 15.61 \\
\hline $\begin{array}{c}\text { standard } \\
\text { deviation }\end{array}$ & 7.23 & 0.49 & 3.44 & 434.68 & 76.12 & 115.65 & 195.73 & 428.65 & 1.48 \\
\hline
\end{tabular}

\section{Colinearity test}

The collinearity test was performed on the collected sample data of reward crowdfunding projects. The results are shown in Table-3.

Table-3: Results of the collinearity test

\begin{tabular}{|c|c|c|c|c|c|c|c|c|c|}
\hline & Images & Video & Rewards & Min-inv & Updates & Reviews & Min-inv_backers & Backers & Ln_goal \\
\hline Tolerance & 0.828 & 0.895 & 0.799 & 0.971 & 0.487 & 0.593 & 0.204 & 0.171 & 0.925 \\
\hline VIF & 1.207 & 1.117 & 1.251 & 1.029 & 2.053 & 1.686 & 4.902 & 5.843 & 1.081 \\
\hline
\end{tabular}

The results in the table show that variance inflation factor (VIF) value of the explanatory variable is 5.843 at the maximum, and the remainder is less than 5, which indicates that there is no serious collinearity problem among the explanatory variables, and the regression analysis can be performed in the next step.

\section{LOGISTIC REGRESSION RESULTS}

Prior to regression analysis, the processing of control variables was the introduction of dummy variables. There are three types of item types: type of technology and design, type of cartoon movie and video games, and other types. Two corresponding dummy variables ItemA and ItemB are introduced. The collected sample data comes from three different crowdfunding platforms, so the corresponding two dummy variables PlatA, PlatB are also introduced. Using Eviews8.0 and SPSS20 software for regression analysis, the regression results are shown in Table-4. The results show that, apart from the fact that the video and number of return levels have no significant effect on the successful financing of crowdfunding projects, the remaining explanatory variables have significant impact on the successful financing.

Table-4: Regression results

\begin{tabular}{|c|c|c|c|}
\hline \multicolumn{2}{|c|}{ Explanatory Variables } & Regression Coefficients & Significant Level \\
\hline \multicolumn{2}{|c|}{ Images } & $0.0258^{* * *}$ & 0.0014 \\
\hline \multicolumn{2}{|c|}{ Video } & 0.1714 & 0.1122 \\
\hline \multicolumn{2}{|c|}{ Rewards } & 0.0110 & 0.5560 \\
\hline \multicolumn{2}{|c|}{ Min-inv } & $0.0002 * * *$ & 0.0000 \\
\hline \multicolumn{2}{|c|}{ Updates } & $0.0245 * * *$ & 0.0000 \\
\hline \multicolumn{2}{|c|}{ Reviews } & $0.0094 * * *$ & 0.0001 \\
\hline \multicolumn{2}{|c|}{ Min-inv backers } & $0.0272 * * *$ & 0.0000 \\
\hline \multicolumn{2}{|c|}{ Backers } & $0.0070 * * *$ & 0.0000 \\
\hline \multicolumn{2}{|c|}{ Ln_goal } & $-0.6341 * * *$ & 0.0000 \\
\hline \multicolumn{4}{|c|}{ Control Variables } \\
\hline \multirow[t]{2}{*}{ Platform } & PlatA & $-0.5518 * * *$ & 0.0035 \\
\hline & PlatB & $-0.3078 * *$ & 0.0216 \\
\hline \multirow[t]{2}{*}{ Type } & ItemA & -0.2353 & 0.1427 \\
\hline & ItemB & -0.0697 & 0.5790 \\
\hline \multicolumn{2}{|l|}{ Constant } & $4.1380 * * *$ & 0.0000 \\
\hline \multicolumn{2}{|l|}{ Pseudo $\mathrm{R}^{2}$} & \multicolumn{2}{|c|}{0.3107} \\
\hline \multicolumn{2}{|l|}{ Sample size } & \multicolumn{2}{|l|}{2817} \\
\hline
\end{tabular}

Note: *,**, and *** indicate that the corresponding $P$-value is significant at the levels of $0.1,0.05$, and 0.01 , respectively

In the attractive process of quality signals of crowdfunding projects to investors, the $P$-value of number of project pictures is less than 0.01 , which has a very significant impact on successful financing of crowdfunding projects and positively affects the rate of financing success. This indicates that the more pictures in description of crowdfunding project, the better quality signal of the project can be released to investors. The minimum investment (Min-inv) has a $P$ value of 0.0000 and a regression coefficient of 0.0002 , which shows that it can significantly and positively affect the successful financing of the project, but the effect is small. Whether the project description has video and number of return levels have not passed the significance test, but they both have a positive impact on the successful financing of the project. 
In interactive trust process between fundraisers and investors, the $P$-value of number of project updates and reviews are less than 0.01 , which positively and significantly affect the financing success of the project, indicating that they are very important factors for investors to generate trust about the project during the interaction process.

In the process of investors' funds to support crowdfunding project, the explanatory variable of backer's number of minimum investment and project backer's number can reflect the degree of attraction of the lowest and other return levels to investors. Their corresponding $P$-values are all less than 0.01 , indicating that they can significantly and positively affect successful financing. The $P$-value of amount of financing goal is also less than 0.01 , but the regression coefficient is negative, which shows that it can significantly but negatively affect the financing success of the project. And this result is consistent with previous scholars' conclusions on the target financing amount.

\section{RESEARCH CONCLUSIONS}

Based on the theory of quality signals and trust, this paper constructs a financing process for investors to support crowdfunding projects, and divides processes of investment decision-making into three stages, including: the attraction process of project quality signals, the interactive trust process, and the final process investor's funds to support project. From the above three processes, important factors were selected to construct a corresponding research model, and project datas of well-known and representative crowdfunding platforms were collected to empirically analyze the factors affecting successful financing. The research conclusions obtained are as follows. In the attractive process of quality signals, the number of project pictures and the minimum investment amount are significant and positively affecting the successful financing of the project. Whether the project description has video and number of return levels is not significant, but they have a positive impact on successful financing. In the interactive trust process, the number of updates and reviews in the project are very significant, which indicate that the investor's trust about the project during the interactive process is the key factor in promoting the investor's funds to support the project. In the process of investor's funds to support project, both the number of backers and the supporters of minimum investment significantly affect successful financing, and the amount of financing goal significantly negatively influences the financing result.

\section{REFERENCES}

1. Jiao, W., \& Liu, M. (2014). The Crowdfunding in the Era of Social Media: Review and Prospect of Foreign Studies. Journal of Zhongnan University of Economics and Law, 5:65-71.

2. Agrawal, A., Catalini, C., \& Goldfarb, A. (2011). The geography of crowdfunding. National Bureau of Economic Research.

3. Mollick, E. (2014). The dynamics of crowdfunding: An exploratory study. Journal of Business Venturing, 29(1):116.

4. Boeuf, B., Darveau, J., \& Legoux, R. (2014). Financing Creativity: Crowdfunding as a new approach for Theatre Project. International Journal of Arts Management, 16(3):33-49.

5. Ahlers, G. K., Cumming, D. J., Gunther, C., \& Schweizer, D. (2015). Signaling in Equity Crowdfunding. Entrepreneurship Theory and Practice, 39(4):955-980.

6. Frydrych, D., Bock, A. J., Kinder, T., \& Koeck, B. (2014). Exploring entrepreneurial legitimacy in reward-based crowdfunding. Venture Capital: An International Journal of Entrepreneurial Finance, 16(3):247-269.

7. Kuppuswamy, V., \& Bayus, B. (2013). Crowdfunding Creative Ideas: The Dynamics of Project Backers in Kickstarter. UNC Kenan-Flagler Research Paper.

8. Cumming, D., Leboeuf, G., \& Schwienbacher, A. (2014). Crowdfunding Models: Keep-It-All vs. All-Or-Nothing. SSRN Electronic Journal, doi:10.2139/ssrn.2234765.

9. Moutinho, N., \& Leite, P. (2013). Critical Success Factors In Crowdfunding: The Case of Kickstarter. https://repositorio-aberto.up.pt/bitstream/10216/71581/2/51556.pdf

10. Zhao, B., \& Wang, S. (2016). Analysis on Factors Influencing the Success of Crowd-funding Projects: Based on the Perspective of Value Co-creation. Journal of Central University of Finance and Economics, 9:40-47.

11. Chen, Y., Ni, N., \& Gou, X. (2015). Research on Factors Influencing the Success of Crowdfunding Projects Based on the Innovation and Entrepreneurship Environment. Shanghai Economic Research, 11:12-19.

12. Yao, Z., Chen, X., \& Zhang, X. (2016). Research of Factors in Crowd Funding Financing Based on Quality Signal Theory. Research on Financial Economics, 4:60-71.

13. Huang, J., Huang, X., \& Wang, T. (2017). Research on Factors and Forecasting Model of Crowdfunding Project Financing Success. Chinese Soft Science, 7:91-100.

14. Zheng, H., Huang, Y., \& Yin, G. (2015). Antecedents of Equity-based Crowdfunding Success for Innovation Projects. Chinese Soft Science, 1:130-138.

15. Gefen, D., Rose, G., \& Warkentin, M. (2015). Cultural diversity and trust in IT adoption: A comparison of USA and South African e-voters. Journal of Global Information Management, 13(1):54-78.

16. Jiang, X. (2014). Crowdfunding Publishers' Willingness to Pay for Research Based Trust Theory. Technology and Publishing, 5:18-21. 